\title{
Perceptions of post-multicurrency regime financial inclusion confidence challenges in Zimbabwe
}

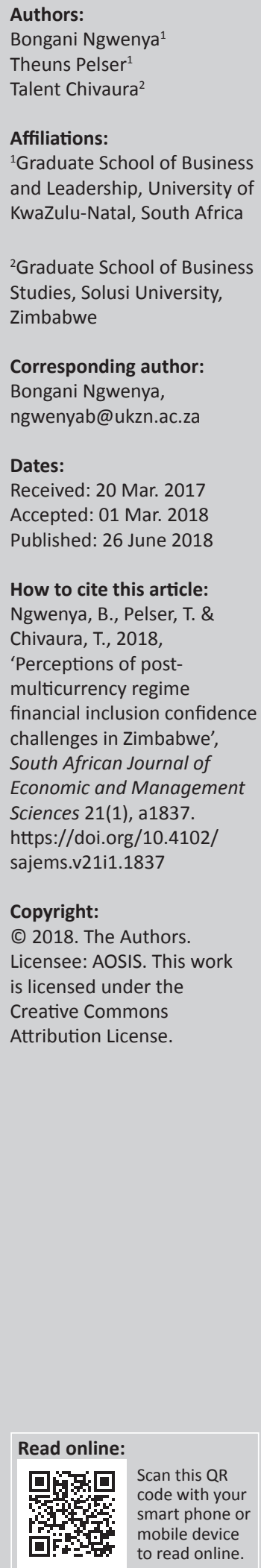

Aim: The study sought to assess the informal trader's perceptions of the post-multicurrency regime financial inclusion confidence challenges in Zimbabwe and also through further future studies explore the potential of explicating a framework for achieving optimal financial inclusion in an economy recovering from a recession through further future studies.

Setting: A non-probability judgment sample of 1000 informal traders in the Avondale area of Harare was used in this study.

Method: The study established four potential financial inclusion construct pillars: demand side factors, supply side factors, behavioural factors and individual factors; these were largely influenced by age, which can be investigated in further future grounded theory studies to develop a framework.

Results: The results indicate that healing from the financial experiences of the hyperinflation era of 2008 still has not been achieved. The study suggests a need for Zimbabwe to restore human rights, political stability, and ensure compliance with the Financial Action Task Force regulations regarding money laundering and terror financing in order to boost external confidence in the financial system of the country.

Conclusion: There is still a challenge of confidence in the country's financial system. The proposed framework is envisaged to minimise the negative impacts of the mistrust of formal financial service providers and boost confidence in the financial system. It is hoped that the findings will aid government to craft policies that will be perceived as supportive of the informal sector to achieve optimal financial inclusion. The study further suggests penetration of the rural areas through technological advances such as mobile networks.

\section{Introduction}

According to the Zimbabwe National Statistic Agency (ZimStat 2016) the Zimbabwean economy started experiencing a severe liquidity crisis towards the last quarter of 2015 because of a declining money supply. When the country adopted the multicurrency regime in 2009, the monetary authority, the Reserve Bank of Zimbabwe (RBZ), ceded its monetary policy sovereignty. Particularly, the RBZ lost the ability to engage in seigniorage, which includes printing of bank notes, either to replace the worn notes or to meet money supply needs in response to productive demand in the economy.

The money supply shortfall did not only affect money circulation, but also credit supply by financial institutions, as well as consumer spending propensity. Deflation literature suggests that the net effect should be that bank deposits, not cash, should account for the bulk of the money supply in the economy (Anderloni \& Carluccio 2006; Braga 2006; Corr 2006; Memdani \& Rajyalakshmi 2013).

The ZimStat (2016) on money supply indicates that money supply had risen to $\$$ US4,75 billion by the end of 2015, attributing to improving confidence in the banking sector from the all-time low confidence experienced during the hyperinflation of 2008. It is worth noting that the banks' lending portfolio is currently skewed towards lending for consumptive purposes, and bank deposits are largely skewed towards demand deposits. This phenomenon is not healthy for money creation and liquidity improvement.

Regardless of the growing domestic confidence after the hyperinflation era, a significant proportion of the population of Zimbabweans is still financially excluded. Studies conducted so far indicate that much of the Zimbabwean population that is financially included, is so mainly for transactional purposes such as receiving salaries and other money deposits from employment 
and other sources (Anderloni \& Carluccio 2006; BMRB 2006; Braga 2006; Corr 2006; Kempson 2006; Makoni 2010; Noko 2011).

The propensity to save is generally low because of average low disposable incomes. Most adults in Zimbabwe do not save because of lack of residual income after paying for living expenses, school fees and emergencies. Usually the portion of income allocated for emergencies is kept as savings at home. On the other hand, bank deposit and savings interest rates that banks offer are significantly low and unattractive (Makoni 2010).

According to ZimStat (2016) about \$US7,4 billion is being speculated in the informal sector of Zimbabwe's economy. This has prompted the Government of Zimbabwe to formalise the operations of the informal sector in the country in fulfilment of the Zimbabwe Agenda for Sustainable SocioEconomic Transformation (ZIMASSET).

The government acknowledges that the fiscus is losing substantial amounts of money from this untapped sector and formalising such activities would go a long way to achieving the objective of financial inclusion. However, the challenge of domestic and external confidence still exists. Zimbabwe currently has an investor confidence averaging -37.2 as of the last quarter of 2016 (ZimStat 2016). This has prompted this study to examine the informal traders' financial inclusion confidence challenges in Zimbabwe, after the adoption of the multicurrency regime.

From here the authors proceed as follows: a comprehensive literature review is undertaken, followed by an outline of the problem and research questions. The research methodology that informs the collection of data is critically examined, followed by the analysis of results, limitations of the study, recommendations and conclusions thereto.

\section{The background of multicurrency regime}

IMF-Zimbabwe (2010) says that the hyperinflation of 2008 saw the abandonment of the Zimbabwe dollar in transactions and de facto widespread dollarisation or multicurrency regime adoption. The Zimbabwe dollar was officially recognised as demised in February 2009, when the Zimbabwean authorities established a multicurrency system. Under the multicurrency regime or system, transactions in hard foreign currencies were authorised after having been taboo, payments of taxes became mandatory in foreign exchange, and the exchange system became largely liberalised.

Since the abolition of all surrender requirements on foreign exchange earnings and proceeds on 19 March 2009, there has not been a functioning foreign exchange market for the Zimbabwe dollars that were finally demonetised in 2015. All the bank accounts that were denominated in Zimbabwe dollars (equivalent to about \$US6 million at the exchange rate of \$Z35 quadrillion per \$US1) became dormant. The use of the Zimbabwe dollar as domestic currency was initially scheduled to be discontinued until 2012. However, the multicurrency use was extended beyond 2012 for an indefinite period. There are five foreign currencies that have been granted official status in Zimbabwe since 2009; however, the US dollar became the principal currency. Since 2009, fiscal revenue estimates and fiscal expenditure allocations have been denominated in US dollars.

The multicurrency regime provided significant benefits such as fostering the re-monetisation of the Zimbabwean economy and financial reintermediation; it also helped enforce fiscal discipline by curtailing government inflationary financing of the fiscus, and brought in greater transparency in pricing of goods and services and accounting after the period of hyperinflation. Accordingly, the price levels in US dollars started falling during 2009, while the economy started to recover and rebound (IMF-Zimbabwe 2010).

\section{Related literature review}

\section{The informal sector}

According to Lee and Viuvarelli (2004) it is noted that there is a direct relationship between economic structural adjustment programmes (ESAP) in developing countries and the growth of the informal sector, due to increased unemployment that the imposed structural programmes tend to cause. It is therefore beyond argument that ESAP in Zimbabwe contributed significantly to structural unemployment in the country. With fewer persons of the income-generating age with families to support being employed, the trend of crossing the border to other countries such as South Africa, to buy goods for resale has gained popularity (Gupte, Venkataramani \& Gupta 2012; Nuewirth 2012).

The International Labour Organisation (2015) broadly characterises the informal sector as consisting of units engaged in the production of goods or services with the primary objective of generating employment and incomes to the persons concerned. These units typically operate at a low level of organisation, with little or no division between labour and capital as factors of production and on a small scale.

The informal sector can be classified into four perspectives which were propounded by Hussmanns (2004) and reiterated in HM Treasury (2004). Firstly, it can be viewed in a positive way as a provider of employment and income to millions of people who would otherwise lack the means of survival. Secondly, it can be viewed more negatively as a whole segment of society that escapes regulation and protection. Thirdly, it can be romanticised as a place where entrepreneurship could flourish if it were not encumbered by unnecessary regulation and bureaucracy. Fourthly, it can be condemned as a vast area of backwardness, poverty, unsanitary conditions for hazardous work, illegality and open use of child labour (Cull Demirgüç-Kunt \& Lyman 2012; Demirgüç-Kunt \& Klapper 2012a; Njaya 2015). 


\section{Financial inclusion}

Financial inclusion as a key enabler for development is firmly placed on the agenda of most governments as a key policy priority (Atkinson \& Messy 2013; Chakravarty \& Pal 2013; Morgan \& Pontines 2014; Sarma 2008, 2012). Financial inclusion or inclusive financing refers to the delivery of financial services at affordable costs to sections of disadvantaged and low-income segments of society (FINCA 2016). The Reserve Bank of Zimbabwe Financial Inclusion (2016) report highlights that in the Zimbabwean context financial inclusion is the effective use of a wide range of quality, affordable and accessible financial services, provided in a fair and transparent manner through formal or regulated entities, for all Zimbabweans. Kairiza, Kiprono and Magadzire (2016) are in support of the RBZ report.

The term financial exclusion refers to the situation where people have difficulties in accessing suitable financial services within the traditional financial market. FINCA (2016) defines financial exclusion as the unavailability of banking services to people with low income. Consumers are not homogenous and the causes of exclusion are complex and varied (Mago 2014; Munyanyi 2013, 2014; Ndlovu \& Ndlovu 2013). Moreover, the number of consumers affected naturally depends on the product sector (FINCA 2016).

According to Financial Inclusion Centre of the UK (2016), there are various factors that lead to financial exclusion which include a combination of low disposable incomes and the economics of access in retail financial services.

The Financial Scope Survey Zimbabwe (2016) reveals that the level of financial inclusion in the small and medium enterprises (SMEs) sector was significantly low with the following key statistics: (1) only $14 \%$ of SME owners are banked, that is, use formal financial products and services offered by a commercial bank; (2) the majority of business owners do not use or have a bank account for business purposes; (3) $50 \%$ of business owners (1.4 million) have or use informal mechanisms to manage their business finances;

(4) $18 \%$ of business owners (475 000) are formally served, including both bank and other formal non-bank products and services. Also worth noting is that only $30 \%$ of Zimbabwe's adult population made use of banking services as at 2014 (Chitokwindo, Mago \& Hofisi 2014; Shankar 2007).

The Financial Scope Survey (2016) report notes that the majority $(58 \%)$ of adult Zimbabweans do not borrow. Out of those who do not borrow, $48 \%$ cited the fear of debt as their reason for failing to borrow, while $45 \%$ indicated that they do not have an ability to borrow. The Financial Scope Survey also indicated that there is reliance on informal sources of credit which catered for $30 \%$ of adult borrowings, while formal credit accounted for only $13 \%$ of adult credit in 2014.

Several studies in the literature suggest that financial inclusion is generally driven by population density, especially in Africa (Allen et al. 2014; Arun \& Kamath 2015; De Koker \& Jentzsch 2013). These studies emphasise that population density is linked more to bank branch penetration in Africa than it is in other developing economies. However, most of the studies have found a nonlinear relationship between population density and banking sector development, with the largest gap between Africa and the rest of the developing world experienced in those African countries trapped in the low density area. This suggests that the minimum, viable banking scale in Africa is perhaps greater than elsewhere, Zimbabwe inclusive (Kodan 2011; Lindsey et al. 2011; Memdani \& Rajyalakshmi 2013; Morgan \& Pontines 2014; Sarma 2011, 2012).

\section{External environmental factors}

The Global Microscope (2015) reports that there are 12 indicators that enable the environment for financial inclusion. These include:

- Government support for financial inclusion demonstrated by a country having a documented strategy on financial inclusion, as well as the government having a database containing customer level data that helps to understand low-income populations' demand for financial services.

- Regulatory and supervisory capacity for financial inclusion. There must be a recent technical support system that supervises operations, prudential regulation, the presence of appropriate entry and licensing requirements, as well as an enabling environment for ease of operations.

- Regulation and supervision of credit portfolios exist along with interest rate caps for credit that do not distort the market. There is also active supervision of the status of over-indebtedness for credit portfolios, as well as a differentiated and comprehensive risk management framework for micro credit.

- Regulation and supervision of deposit-taking activities, ensuring that there are ease-offering savings and products by regulated institutions as well as the existence of indepth deposit insurance coverage.

- Regulation of insurance targeting low-income populations; there must be delivery channels and consumer protection for insurance targeting low-income populations.

- Regulation and supervision of branches and agents, the ease of setting up branches as well as agent operations.

- Requirements for non-regulated lenders, the existence of information reporting and operational guidelines.

- Electronic payments: the availability of infrastructure for financial inclusion and digital financial services.

- Credit reporting systems: the information stored by credit reporting systems should be comprehensive, regularly updated and accessed by providers.

- There must also be protection for both borrowers and lenders.

- Market conduct rules encompassed in the existence of a framework and institutional capacity to protect the financial consumer, disclosure rules and fair treatment rules. 
- Grievance redress and operation of dispute resolution mechanisms found in internal complaint mechanisms and the existence and effectiveness of a third-party redress entity.

The Financial Inclusion Centre of the UK (2016) notes that government and regulatory policy might have the unintended consequences of consumers inadvertently contributing to financial exclusion or making it more difficult for consumers to provide for themselves. The researchers agree with the two bodies that their findings are applicable to the Zimbabwean situation.

The Zimbabwe Economic Policy Analysis and Research Unit (ZEPARU 2014) indicates that riskiness of lending because of poor management and high rate of business failure, high administrative cost, low productivity, undercapitalisation, shortage of skills, aversion to disclosure of information and lack of collateral are some of the constraints that have been identified as hindering informal sector development. Access to formal financing channels by the informal sector is a vital step in formalising their business (Owusu-Ansah 2000).

\section{Societal factors}

Ncube (2013) suggests that the informal economy is associated with criminal endeavours and tax evasion practices. Siyaso in Mbare and Gazaland for example are traditionally regarded as the hub of all illegal trade where sale of stolen products and other criminal activities are done daily. This notion that being informal is illegal, discourages banks from advancing loans to the sector since, by law, they are not allowed to deal with criminals (Financial Inclusion Centre UK 2016).

The bulk of informal traders lack enough recognisable collateral and this is explained further by Adisu (2006) who notes that a common characteristic in developing nations is that financial institutions are faced with a considerable default rate. Beck and De la Torre (2006) hold the view that some informal traders are discouraged from borrowing by the fact that their future earnings are usually less than the value of their assets.

\section{Individual factors}

The RBZ's National Financial Inclusion Strategy (2016) reveals that income levels and affordability are among the main contributory factors to the current levels of financial exclusion in Zimbabwe. At the same time unemployment levels increase, while the level of disposable income decreases for the average individual and this affects the sales levels and profitability of the informal sector.

The RBZ National Financial Inclusion Strategy (2016) further notes that the following are barriers to financial inclusion within the SME sector: (1) low incomes levels within the SME sector, (2) irregular incomes to support consistent loan repayment requirements, (3) information asymmetries regarding funding options at the disposal of the SMEs and cooperatives, (4) lack of product and service awareness and (5) high and uncompetitive interest rates and bank charges offered by financial institutions.

\section{Demand side factors}

The barriers to access that can undermine consumers' willingness to engage with financial services or affect capacity may be termed demand side factors. These barriers include: financial capability, the cost of doing business with financial institutions, consumer trust and confidence. The net result of these barriers is that consumers may self-exclude to a large degree (World Bank 2016). Demirgüç-Kunt and Klapper (2012b) suggest that price and income are the most notable economic detriments in the demand for payment and saving services.

Demand is not affected by economic factors only but also by socio-cultural ones such as religion which may lead to self-exclusion (Claessens 2006). Ghatak (2013) identifies accessibility, culture, assets, income and literacy as the main demand side factors that influence financial inclusion.

Shankar (2013) argues that financial literacy and financial capability are of utmost importance in the demand side factors influencing financial inclusion. Financial literacy refers to the basic understanding of financial concepts, while financial capability refers to the ability and motivation to plan financials, seek out information and advice and apply these to personal circumstances (Chakraborry 2003).

\section{Behavioural factors}

According to the Financial Inclusion Centre of the UK (2016), barriers to access that may undermine consumers' willingness to engage with financial services and affect the ability to make effective, informed choices and decisions may be termed behavioural factors. These barriers include: low levels of consumer awareness of the need to plan and provide for the future, or shop around for better deals, and low levels of financial literacy, consumer trust and confidence.

These could lead to self-exclusion. Chakraborry (2012) concludes that barriers to financial inclusion include: low literacy levels, being a lack of awareness and understanding of financial products, irregular income, frequent microtransactions, lack of trust in formal banking institutions as well as cultural obstacles such as religion and cultural values.

\section{Supply side factors}

Ghatak (2013) suggests that the key barriers to financial supply are: distribution inefficiencies, ineffective competition, over- or under-supply in the market and diseconomies of scale, complex products, inefficient regulation, public policy interaction and basic economics of access. Chakraborry (2012) cites outreach, regulation, business models, services, age and bank charges as the supply side factors influencing financial inclusion. 
The emergence of informal savings clubs, stokvels and burial societies point to the need for saving for the consumers who do not have access to formal financial services that are accessible and affordable. The report further says that the financially excluded are keen to be included but the financial systems shut them out. The combined mobile money subscriber base for example had reached 6 million as at 30 September 2015, and there were more than 30000 mobile payment agents across the country, a huge growth from 6000 in 2013 (RBZ National Financial Inclusion Strategy 2016).

\section{Problem statement and research questions}

The immediate benefits of the multicurrency regime were the taming of the hyperinflation over night, and instillation of financial discipline on the government's part. However, the management of the supply side of the multicurrencies has been a nightmare for the Government of Zimbabwe, particularly the harnessing of the multicurrency circulating in the domestic economy through financial inclusion. Financial inclusion is identified as one of the pillars for success of the ZIMASSET.

Research on financial inclusion has become increasingly prevalent with the consensus being that the inclusion of everyone in the financial activities is the only way to go. A government Prices, Incomes, Consumption and Expenditure Survey (PICES 2012) report concluded that, while unemployment by conventional definitions is estimated at about $92 \%$, those who are not necessarily employed but are gainfully engaged stand at over $90 \%$, attributable to the economic evolution taking place, that is, economic informalisation.

Statistics released by the FinScope survey of SMEs in 2012 supported this assertion by revealing that there are more than 2 million individual entrepreneurs and 800000 SMEs with employees estimated to be way above the 2.9 million people marker. Survey reports on financial inclusion estimated that the informal sector has as much as \$US7.4 billion circulating outside the formal financial system, that is, depriving the economy the much-needed financial resources. This, therefore, prompted this study to seek to investigate the informal sector's perceptions of financial inclusion challenges, post-multicurrency adoption (FinScope 2016).

The study premises that there is a critical need at macroeconomic planning level to understand the key factors that lead to a successful financial inclusion strategy; these are: external environmental factors, societal factors, individual factors, demand side factors, behavioural factors and supply side factors. The main purpose of this study is to investigate the informal sector's perceptions of financial inclusion challenges that have become synonymous with the post-multicurrency regime adoption era in Zimbabwe. The critical problem addressed by this study is the need for the Government of Zimbabwe and particularly the financial authorities to develop a contextualised framework for achieving the financial inclusion objectives of the ZIMASSET. The study focuses on the following five critical research questions:

- What is the general status of financial inclusion among the selected informal traders in Harare?

- To what extent do the selected informal traders in Harare perceive the following as financial inclusion confidence challenges in Zimbabwe?

- External environmental factors

- Societal factors

- Individual factors

- Demand side factors

- Behavioural factors

- Supply side factors

- Is there a difference in the perception of the financial inclusion confidence challenges in Zimbabwe in relation to demographic characteristics of the selected informal traders in Harare?

- What are the perceived dominant dimensions of financial inclusion confidence challenges as extracted by factor analysis?

\section{Research methodology}

The study attempted to investigate and ascertain perceptions, attitudes and challenges that SMEs and other informal sector players have that have forced them to 'shun' the formal financial system. Specific focus is on:

- Establishing the challenges faced by people who make up the informal sector in accessing formal financial products and services.

- Exploring options that are there for consideration to facilitate the inclusion of informal traders into the formal financial system.

- Identifying policy constraints affecting the financial inclusion of the informal sector.

- Coming up with recommendations on how the formal financial sector can rake in the financial resources that remain unbanked in the country.

\section{Data collection and sample selection}

A survey of informal traders concentrated in the Avondale area of Harare, the capital city of Zimbabwe, was conducted using a questionnaire. Since the achievement of an all financial inclusive strategy by the financial sector planners in Zimbabwe could be more affected by the perceptions and attitudes of the financially excluded sectors of the society, such as the informal traders, it was assumed that the informal traders are a homogenous representative of the financially excluded constituency of the Zimbabwean society and would be more likely to have homogenous characteristics and representative interests.

A purposive sample of 1000 informal traders from the registered 15863 informal traders in the Avondale area of Harare were asked to complete a self-administered hard copy distributed questionnaire designed to gather data regarding 
their perceptions and attitude towards financial inclusion. The questionnaire requested data on the specific perception factor constructs surrounding the financial inclusion trajectory by the financial sector in Zimbabwe: external environmental factors, societal factors, individual factors, demand side factors, behavioural factors and supply side factors. All 1000 responses were ultimately received and used for the purposes of this study.

Research questions 1 and 2 were answered by use of statistical frequencies, that is, to determine the demographic characteristics of the respondents and the general status of financial inclusion among the selected informal traders in Harare. Descriptive statistics of central tendency and measures of variability were used to answer research question number 3, that is, to measure the extent to which the selected informal traders perceived external environmental factors, societal factors, individual factors, behavioural factors, demand side factors and supply side factors as financial inclusion confidence challenges in Zimbabwe.

Research question 4, which dealt with difference in the perception of the financial inclusion confidence challenges in Zimbabwe in relation to demographic characteristics of the selected informal traders in Harare, was answered by the t-tests, analysis of variance and post-hoc analysis. Factor analysis was used to answer research question 5 and thus reduced the perception constructs on financial inclusion into four identifiable factors.

\section{Demographic characteristics}

The sample from which data was collected was 1000 respondents drawn from various informal sector markets within Harare.

Of the total respondents $47 \%$ were men and $53 \%$ were women as shown in Figure 1.

All the respondents were African with age frequencies of $8 \%$ for respondents aged between 18 and 30 years, 48\% aged between 31 and 40 years, 30\% aged between $41-50$ years and $14 \%$ above 50 years (see Figure 2).

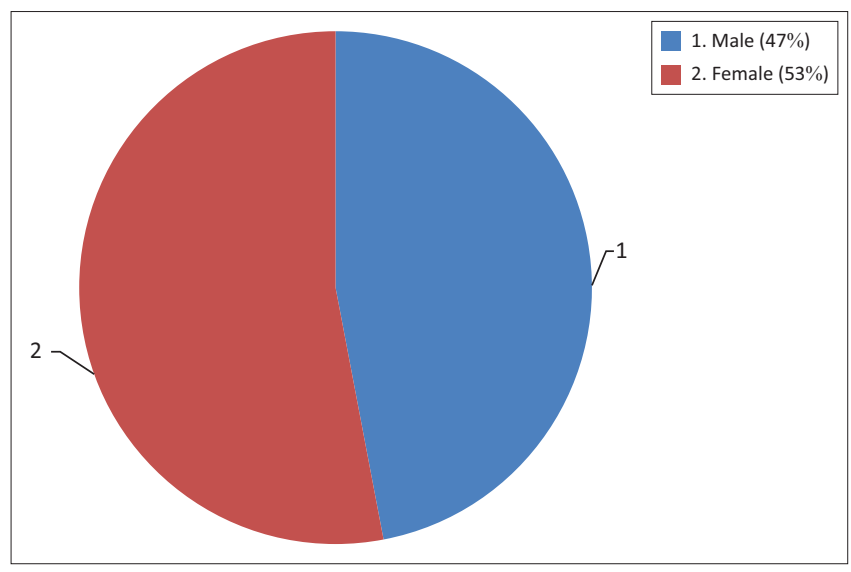

FIGURE 1: Gender.
Figure 3 shows that most of the informal traders who responded are selling clothing items, represented by the $36 \%$ and commodity brokers 35\%. Other business ventures being explored include hairdressing, airtime vending, dressmaking (tailors), car dealing and vegetable vending.

Figure 4 shows the number of years of employment within the informal sector. Fourteen per cent $(14 \%)$ had $0-5$ years working experience, $59 \%$ had 5 to 10 years working

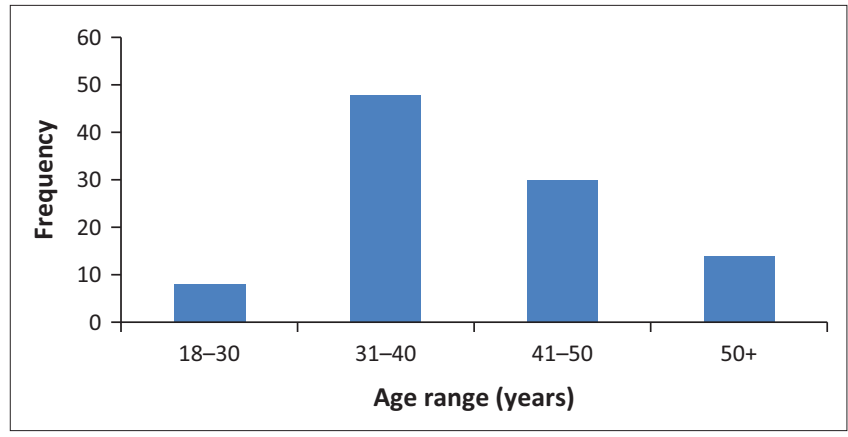

FIGURE 2: Age distribution.

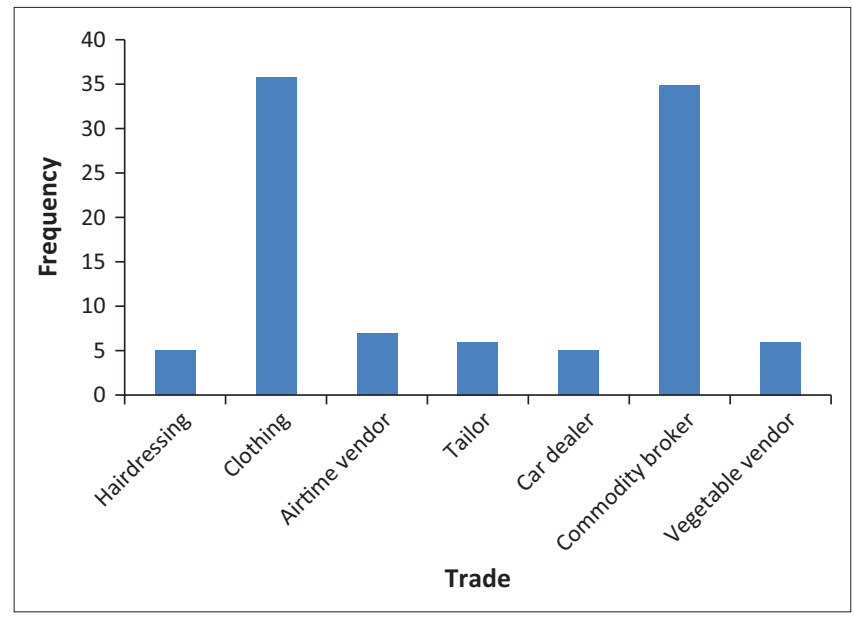

FIGURE 3: Businesses run by respondents.

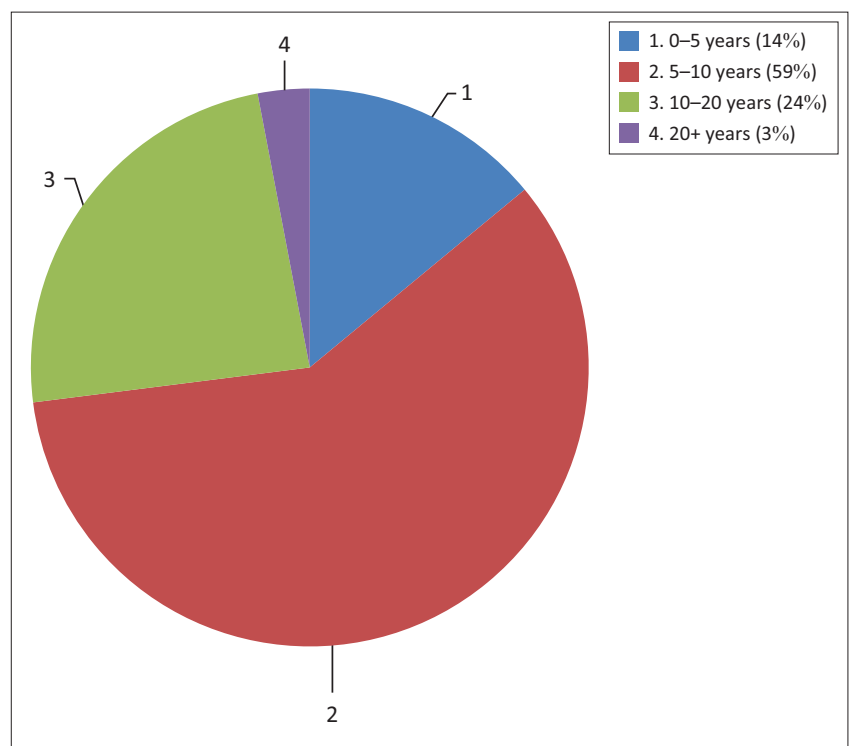

FIGURE 4: Years of employment within the informal sector. 
experience, $24 \%$ had 10 to 20 years working experience and $3 \%$ had 20 or more years of working experience in the informal sector.

The monthly income of informal traders plying their goods in the Avondale area ranges from $\$ 0$ to more than $\$ 2000$. Sixty-four per cent (64\%) earn between $\$ 0$ and $\$ 500,27 \%$ earn between $\$ 501$ and \$1000, 6\% earn between \$1001 and \$2000 and 3\% earn more than \$2001, as shown in Figure 5.

\section{Analysis of results}

\section{Descriptive statistics: General status of financial inclusion among the selected informal traders}

The study revealed that $68 \%$ of the respondents do not have a bank account while only $32 \%$ have a bank account. Meanwhile $17 \%$ of the respondents have a bank loan such as a mortgage or personal loan and $63 \%$ do not have any loans with financial services providers. This points to most informal traders lacking bank accounts and not borrowing from financial services providers as depicted in Figure 6.

\section{Descriptive statistics: External environmental factors}

Table 1 shows the basic descriptive statistics of central tendency and measures of variability for the external environmental factors, one of the pillars of financial inclusion, as indicated by variables Q10-Q13.

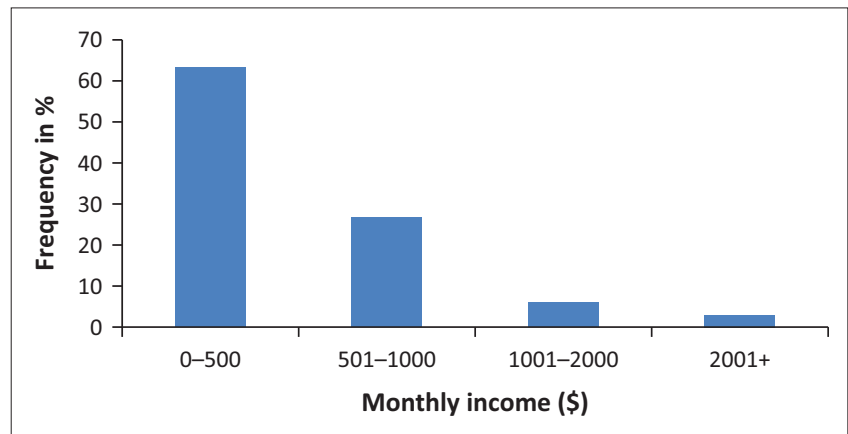

FIGURE 5: Monthly income.

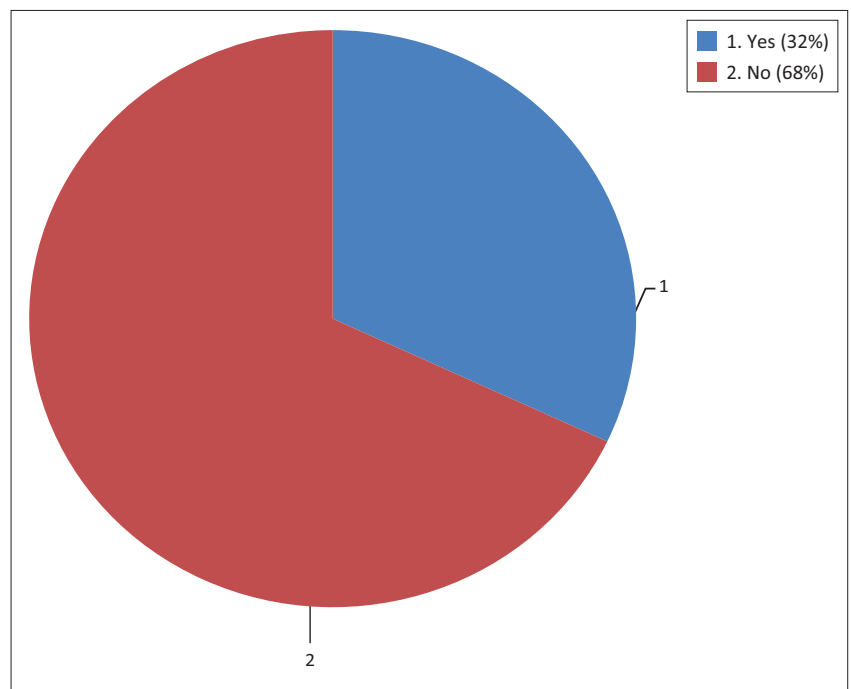

FIGURE 6: Respondents' ownership of bank account.
The range corresponds to the numerical value of 4 . The minimum value (1) refers to the response 'strongly disagree' and the maximum value (5) refers to the response 'strongly agree', with the highest mean score turning out to be 3.93 for variable Q13. The arithmetic average of the scores for variable Q13 indicates that the informal sector comprises people capable of utilising formal financial services when given a chance. The lowest mean score turns out to be 2.11 for variable Q10, indicating that the selected informal traders were not aware of the government policies put in place to support their operations financially.

In statistical terms the standard error of the mean is a measure of how much the value of the mean may vary from sample to sample taken from the same distribution (Pelser 2014). In this analysis, the values depicted are relatively low, indicating that the current sample of the selected informal traders does not vary much from or may only slightly vary from another sample. From the highest standard deviation of 1.095 for variable Q11, and the lowest of 0.741 for variable Q10, it is concluded that the sample of the selected informal traders is homogenous and as such the mean of the selected informal traders is consequently representative of the responses.

The skewness measures obtained for the external environmental factor variables indicate that three of the variables (Q10, Q11, and Q13) have negatively skewed distributions (values $<0)$. However, one variable $(\mathrm{Q} 12)$ has positively skewed distribution (values $>0$ ). Nevertheless, no variable falls outside the -1 range. This indicates normal skewed distributions. The kurtosis values obtained for all the variables in Table 1 indicate relatively flat distributions (negative values).

\section{Descriptive statistics: Societal factors}

The descriptive statistics of central tendency and measures of variability for the societal factors, another pillar of financial inclusion, are depicted for variables Q14-Q17 in Table 2. The range for variables Q14-Q17 is 4, with the minimum value (1) and maximum value (5) depicting the responses 'strongly disagree' and 'strongly agree' respectively. The highest mean score is 3.73 for variable Q14 and the lowest mean score is turn 1.80 for variable Q15.

The arithmetic average for the scores for variable Q14 indicate that the selected informal traders believe or perceive that formal financial products and services are for the rich and big corporates only. The average for variable Q15 indicates that the selected informal traders did not agree that the current Zimbabwean financial services sector can be trusted from the experiences of the hyperinflation era of the 2008. In this analysis, the standard error of the mean values is relatively low, indicating that the current sample of the selected informal traders does not vary much from or may only slightly vary from another sample.

From the highest standard deviation of 1.171 for variable Q15 and the lowest of 1.003 for variable Q14, it is concluded that 
TABLE 1: Descriptive statistics: External environmental factors.

\begin{tabular}{|c|c|c|c|c|c|c|c|c|c|c|c|c|}
\hline \multirow[t]{2}{*}{ Variable } & \multirow[t]{2}{*}{$N$} & \multirow[t]{2}{*}{ Range } & \multirow[t]{2}{*}{ Min } & \multirow[t]{2}{*}{ Max } & \multicolumn{2}{|c|}{ Mean } & \multirow{2}{*}{$\begin{array}{l}\text { Standard } \\
\text { deviation }\end{array}$} & \multirow[t]{2}{*}{ Variance } & \multicolumn{2}{|c|}{ Skewness } & \multicolumn{2}{|c|}{ Kurtosis } \\
\hline & & & & & Statistic & $\begin{array}{l}\text { Standard } \\
\text { error }\end{array}$ & & & Statistic & $\begin{array}{l}\text { Standard } \\
\text { error }\end{array}$ & Statistic & $\begin{array}{l}\text { Standard } \\
\text { error }\end{array}$ \\
\hline Q10 & 1000 & 4 & 1 & 3 & 2.11 & 0.014 & 0.741 & 0.5490 & -0.383 & 0.077 & -1.318 & 0.155 \\
\hline Q11 & 1000 & 4 & 1 & 5 & 3.01 & 0.035 & 1.095 & 1.199 & -0.011 & 0.077 & -1.052 & 0.155 \\
\hline Q12 & 1000 & 4 & 1 & 5 & 2.73 & 0.034 & 1.065 & 1.135 & 0.214 & 0.077 & -0.348 & 0.155 \\
\hline Q13 & 1000 & 4 & 1 & 5 & 3.93 & 0.032 & 0.999 & 0.9990 & -1.484 & 0.077 & -1.454 & 0.155 \\
\hline Valid $N$ (listwise) & 1000 & - & - & - & - & - & - & - & - & - & - & - \\
\hline
\end{tabular}

Q, Question; Min, minimum; Max, Maximum.

TABLE 2: Descriptive statistics: Societal factors.

\begin{tabular}{|c|c|c|c|c|c|c|c|c|c|c|c|c|}
\hline \multirow[t]{2}{*}{ Variable } & \multirow[t]{2}{*}{$N$} & \multirow[t]{2}{*}{ Range } & \multirow[t]{2}{*}{ Min } & \multirow[t]{2}{*}{ Max } & \multicolumn{2}{|c|}{ Mean } & \multirow{2}{*}{$\begin{array}{l}\text { Standard } \\
\text { deviation }\end{array}$} & \multirow[t]{2}{*}{ Variance } & \multicolumn{2}{|c|}{ Skewness } & \multicolumn{2}{|c|}{ Kurtosis } \\
\hline & & & & & Statistic & $\begin{array}{l}\text { Standard } \\
\text { error }\end{array}$ & & & Statistic & $\begin{array}{l}\text { Standard } \\
\text { error }\end{array}$ & Statistic & $\begin{array}{c}\text { Standard } \\
\text { error }\end{array}$ \\
\hline Q14 & 1000 & 4 & 1 & 5 & 3.73 & 0.032 & 1.003 & 1.005 & -0.648 & 0.077 & -0.661 & 0.155 \\
\hline Q15 & 1000 & 4 & 1 & 5 & 1.80 & 0.037 & 1.171 & 1.372 & 0.654 & 0.077 & -1.736 & 0.155 \\
\hline Q16 & 1000 & 4 & 1 & 5 & 3.07 & 0.034 & 1.064 & 1.132 & -0.140 & 0.077 & -0.841 & 0.155 \\
\hline Q17 & 1000 & 4 & 1 & 5 & 2.07 & 0.035 & 1.123 & 1.260 & 0.280 & 0.077 & -0.998 & 0.155 \\
\hline Valid $N$ (listwise) & 1000 & - & - & - & - & - & - & - & - & - & - & - \\
\hline
\end{tabular}

Q, Question; Min, minimum; Max, Maximum.

the sample of the selected informal traders is homogenous and as such the mean of the selected informal traders is consequently representative of the responses. The skewness measures obtained for the societal factor variables indicate that two of the variables (Q14 and Q16) have negatively skewed distributions (values $<0$ ). However, the other two variables (Q15 and Q17) have positively skewed distribution (values $>0$ ). Nevertheless, no variable falls outside the -1 range. This indicates normal skewed distributions. The kurtosis values obtained for all the variables in Table 2 indicate relatively flat distributions (negative values) (Pelser 2014).

\section{Descriptive statistics: Individual factors}

Table 3 depicts the descriptive statistics of central tendency and measures of variability for the individual factors affecting the perception on financial inclusion as shown for variables Q18-Q22. The variables Q18-Q22 also have a range 4 , with the minimum value (1) and maximum value (5) representing the responses 'strongly disagree' and 'strongly agree' respectively.

The variable responses have the largest mean value of 3.54 for variable Q22, indicating that the selected informal traders perceived filling in bank forms not an issue and a problem. The smallest mean value of 2.00 is assigned to variable Q21, indicating that the selected informal traders did not believe that the interest rates charged by banks are low. The standard error of the mean values in this analysis is relatively low, indicating that the current sample of the selected informal traders does not vary much from or may only slightly vary from another sample.

From the highest standard deviation of 1.259 for variable Q19 and the lowest of 0.816 for variable Q21, it is concluded that the sample of the selected informal traders is homogenous and as such the mean of the selected informal traders is consequently representative of the responses. The skewness measures obtained for the individual factor variables indicate that three of the variables (Q18, Q19 and Q22) have negatively skewed distributions (values $<0$ ).

The other two variables (Q20, and Q21) have positively skewed distribution (values $>0$ ). However, there is no variable that falls outside the -1 range. This indicates normal skewed distributions. The kurtosis values obtained for all the variables in Table 3 indicate relatively flat distributions (negative values) (Pelser 2014).

\section{Descriptive statistics: Behavioural factors}

Table 4 depicts the descriptive statistics of central tendency and measures of variability for the individual factors affecting the perception on financial inclusion as shown for variables Q23-Q26. The variable Q23-Q26 also have a range 4, with the minimum value (1) and maximum value (5) representing the responses 'strongly disagree' and 'strongly' agree respectively.

The variable responses have the largest mean value of 3.67 for variable Q24, indicating that the selected informal traders perceived savings, investments, unit trusts or shares offered by registered financial service providers as important. The smallest mean value of 3.01 is assigned to the variable Q25, indicating that the selected informal traders were adamant that they would rather use informal channels of saving as opposed to formal channels. The standard error of the mean values in this analysis is relatively low, indicating that the current sample of the selected informal traders does not vary much from or may only slightly vary from another sample.

From the highest standard deviation of 1.340 for variable Q26 and the lowest standard deviation of 0.950 for variable Q23 it is concluded that the sample of the selected informal traders is homogenous and as such the mean of the selected informal traders is consequently representative of the responses. The skewness measures obtained for the individual factor variables indicate that two of the variables (Q23 and Q24) 
TABLE 3: Descriptive statistics: Individual factors.

\begin{tabular}{|c|c|c|c|c|c|c|c|c|c|c|c|c|}
\hline \multirow[t]{2}{*}{ Variable } & \multirow[t]{2}{*}{$N$} & \multirow[t]{2}{*}{ Range } & \multirow[t]{2}{*}{ Min } & \multirow[t]{2}{*}{ Max } & \multicolumn{2}{|c|}{ Mean } & \multirow{2}{*}{$\begin{array}{l}\text { Standard } \\
\text { deviation }\end{array}$} & \multirow[t]{2}{*}{ Variance } & \multicolumn{2}{|c|}{ Skewness } & \multicolumn{2}{|c|}{ Kurtosis } \\
\hline & & & & & Statistic & $\begin{array}{c}\text { Standard } \\
\text { error }\end{array}$ & & & Statistic & $\begin{array}{c}\text { Standard } \\
\text { error }\end{array}$ & Statistic & $\begin{array}{c}\text { Standard } \\
\text { error }\end{array}$ \\
\hline Q18 & 1000 & 4 & 1 & 5 & 3.47 & 0.030 & 0.960 & 0.922 & -1.505 & 0.077 & 0.763 & 0.155 \\
\hline Q19 & 1000 & 4 & 1 & 5 & 3.47 & 0.040 & 1.259 & 1.585 & -0.936 & 0.077 & -0.451 & 0.155 \\
\hline Q20 & 1000 & 4 & 1 & 5 & 2.27 & 0.032 & 0.999 & 0.999 & 1.460 & 0.077 & -1.738 & 0.155 \\
\hline Q21 & 1000 & 4 & 1 & 5 & 2.00 & 0.026 & 0.816 & 0.667 & 0.733 & 0.077 & -0.302 & 0.155 \\
\hline Q22 & 1000 & 4 & 1 & 5 & 3.54 & 0.030 & 0.957 & 0.916 & -1.250 & 0.077 & -1.173 & 0.155 \\
\hline Valid $N$ (listwise) & 1000 & - & - & - & - & - & - & - & - & - & - & - \\
\hline
\end{tabular}

$\mathrm{Q}$, Question; Min, minimum; Max, Maximum.

TABLE 4: Descriptive statistics: Behavioural factors.

\begin{tabular}{|c|c|c|c|c|c|c|c|c|c|c|c|c|}
\hline \multirow[t]{2}{*}{ Variable } & \multirow[t]{2}{*}{$N$} & \multirow[t]{2}{*}{ Range } & \multirow[t]{2}{*}{ Min } & \multirow[t]{2}{*}{ Max } & \multicolumn{2}{|c|}{ Mean } & \multirow{2}{*}{$\begin{array}{l}\text { Standard } \\
\text { deviation }\end{array}$} & \multirow[t]{2}{*}{ Variance } & \multicolumn{2}{|c|}{ Skewness } & \multicolumn{2}{|c|}{ Kurtosis } \\
\hline & & & & & Statistic & $\begin{array}{l}\text { Standard } \\
\text { error }\end{array}$ & & & Statistic & $\begin{array}{c}\text { Standard } \\
\text { error }\end{array}$ & Statistic & $\begin{array}{c}\text { Standard } \\
\text { error }\end{array}$ \\
\hline Q23 & 1000 & 4 & 1 & 5 & 3.60 & 0.030 & 0.950 & 0.902 & -0.992 & 0.077 & -1.440 & 0.155 \\
\hline Q24 & 1000 & 4 & 1 & 5 & 3.67 & 0.038 & 1.193 & 1.423 & -0.761 & 0.077 & -0.372 & 0.155 \\
\hline Q25 & 1000 & 4 & 1 & 5 & 3.01 & 0.035 & 1.098 & 1.205 & 0.007 & 0.077 & -1.059 & 0.155 \\
\hline Q26 & 1000 & 4 & 1 & 5 & 3.07 & 0.042 & 1.340 & 1.794 & 0.135 & 0.077 & -1.437 & 0.155 \\
\hline Valid $N$ (listwise) & 1000 & - & - & - & - & - & - & - & - & - & - & - \\
\hline
\end{tabular}

Q, Question; Min, minimum; Max, Maximum.

TABLE 5: Descriptive statistics: Demand side factors.

\begin{tabular}{|c|c|c|c|c|c|c|c|c|c|c|c|c|}
\hline \multirow[t]{2}{*}{ Variable } & \multirow[t]{2}{*}{$N$} & \multirow[t]{2}{*}{ Range } & \multirow[t]{2}{*}{ Min } & \multirow[t]{2}{*}{ Max } & \multicolumn{2}{|c|}{ Mean } & \multirow{2}{*}{$\begin{array}{l}\text { Standard } \\
\text { deviation }\end{array}$} & \multirow[t]{2}{*}{ Variance } & \multicolumn{2}{|c|}{ Skewness } & \multicolumn{2}{|c|}{ Kurtosis } \\
\hline & & & & & Statistic & $\begin{array}{l}\text { Standard } \\
\text { error }\end{array}$ & & & Statistic & $\begin{array}{l}\text { Standard } \\
\text { error }\end{array}$ & Statistic & $\begin{array}{c}\text { Standard } \\
\text { error }\end{array}$ \\
\hline $\bar{Q} 27$ & 1000 & 4 & 1 & 5 & 2.67 & 0.041 & 1.302 & 1.695 & 0.267 & 0.077 & -1.374 & 0.155 \\
\hline Q28 & 1000 & 4 & 1 & 5 & 3.14 & 0.045 & 1.408 & 1.983 & 0.193 & 0.077 & -1.603 & 0.155 \\
\hline Q29 & 1000 & 4 & 1 & 5 & 2.87 & 0.026 & 0.807 & 0.651 & -0.528 & 0.077 & -0.010 & 0.155 \\
\hline Q30 & 1000 & 4 & 1 & 5 & 3.87 & 0.030 & 0.896 & 0.915 & -0.651 & 0.077 & -0.439 & 0.155 \\
\hline Valid $N$ (listwise) & 1000 & - & - & - & - & - & - & - & - & - & - & - \\
\hline
\end{tabular}

Q, Question; Min, minimum; Max, Maximum.

have negatively skewed distributions (values $<0$ ), while the other two variables (Q25 and Q26) have positively skewed distribution (values $>0$ ). However, no variable falls outside the -1 range. This indicates normal skewed distributions. The kurtosis values obtained for all the variables in Table 4 indicate relatively flat distributions (negative values) (Pelser 2014).

\section{Descriptive statistics: Demand side factors}

The descriptive statistics of central tendency and measures of variability for the demand side factors, another pillar of financial inclusion, are depicted for variables Q27-Q30 in Table 5. The range for variables Q27-Q30 is 4, with the minimum value (1) and maximum value (5) depicting the responses 'strongly disagree' and 'strongly agree' respectively. The highest mean score is 3.87 for variable Q30 and the lowest mean score is 2.67 for variable Q27.

The arithmetic average for the scores for variable Q30 indicate that the selected informal traders strongly think that they would like to access a loan through a registered bank or registered micro finance provider, while that for variable Q27 indicates that the selected informal traders did not agree that they often use their bank accounts for business transactions. In this analysis, the standard error of the mean values is relatively low, indicating that the current sample of the selected informal traders does not vary much from or may only slightly vary from another sample.
From the highest standard deviation of 1.408 for variable Q28 and the lowest of 0.807 for variable Q29, it is concluded that the sample of the selected informal traders is homogenous and as such the mean of the selected informal traders is consequently representative of the responses. The skewness measures obtained for the societal factor variables indicate that two of the variables (Q29, and Q30) have negatively skewed distributions (values $<0$ ). However, the other two variables (Q27, and Q28) have positively skewed distribution (values $>0$ ). Nevertheless, no variable falls outside the -1 range. This indicates normal skewed distributions. The kurtosis values obtained for all the variables in Table 5 indicate relatively flat distributions (negative values) (Pelser 2014).

\section{Descriptive statistics: Supply side factors}

Table 6 depicts the descriptive statistics of central tendency and measures of variability for the individual factors affecting the perception of financial inclusion as shown for variables Q31-Q34. The variables Q31-Q34 also have a range 4, with the minimum value (1) and maximum value (5) representing the responses 'strongly disagree' and 'strongly agree' respectively. The variables responses have the largest mean value of 3.40 for variable Q31, indicating that the selected informal traders were aware of the presence of several registered financial services providers that are available in their area. 
TABLE 6: Descriptive statistics: Supply side factors.

\begin{tabular}{|c|c|c|c|c|c|c|c|c|c|c|c|c|}
\hline \multirow[t]{2}{*}{ Variable } & \multirow[t]{2}{*}{$N$} & \multirow[t]{2}{*}{ Range } & \multirow[t]{2}{*}{ Min } & \multirow[t]{2}{*}{ Max } & \multicolumn{2}{|c|}{ Mean } & \multirow{2}{*}{$\begin{array}{l}\text { Standard } \\
\text { deviation }\end{array}$} & \multirow[t]{2}{*}{ Variance } & \multicolumn{2}{|c|}{ Skewness } & \multicolumn{2}{|c|}{ Kurtosis } \\
\hline & & & & & Statistic & $\begin{array}{l}\text { Standard } \\
\text { error }\end{array}$ & & & Statistic & $\begin{array}{l}\text { Standard } \\
\text { error }\end{array}$ & Statistic & $\begin{array}{l}\text { Standard } \\
\text { error }\end{array}$ \\
\hline Q31 & 1000 & 3 & 1 & 4 & 3.40 & 0.028 & 0.880 & 0.775 & -1.468 & 0.077 & -1.297 & 0.155 \\
\hline Q32 & 1000 & 4 & 1 & 5 & 3.27 & 0.028 & 1.001 & 1.002 & -0.159 & 0.077 & -0.227 & 0.155 \\
\hline Q33 & 1000 & 4 & 1 & 5 & 1.80 & 0.037 & 1.164 & 1.356 & 1.409 & 0.077 & -1.164 & 0.155 \\
\hline Q34 & 1000 & 4 & 1 & 5 & 2.66 & 0.034 & 1.074 & 1.154 & 0.374 & 0.077 & -0.378 & 0.155 \\
\hline Valid $N$ (listwise) & 1000 & - & - & - & - & - & - & - & - & - & - & - \\
\hline
\end{tabular}

Q, Question; Min, minimum; Max, Maximum.

TABLE 7: Independent samples test.

\begin{tabular}{|c|c|c|c|c|c|c|}
\hline \multirow{2}{*}{$\begin{array}{l}\text { Financial inclusion } \\
\text { construct pillar }\end{array}$} & \multirow[t]{2}{*}{ Variable } & \multicolumn{2}{|c|}{ Levene's test for equality of variances } & \multicolumn{3}{|c|}{$t$-Test for equality of means } \\
\hline & & $F$ & Significance & $t$ & $d f$ & Significance (two-tailed) \\
\hline \multirow{2}{*}{$\begin{array}{l}\text { External environmental } \\
\text { factors }\end{array}$} & Equal variances assumed. & 3.410 & 0.065 & -0.181 & 998.000 & 0.856 \\
\hline & Equal variances not assumed. & - & - & 0.182 & 997.980 & 0.856 \\
\hline \multirow[t]{2}{*}{ Societal factors } & Equal variances assumed. & 2.699 & 0.101 & -0.379 & 998.000 & 0.705 \\
\hline & Equal variances not assumed. & - & - & -0.380 & 997.971 & 0.704 \\
\hline Individual factors & Equal variances assumed. & 1.615 & 0.204 & 2.394 & 998.000 & 0.017 \\
\hline \multirow[t]{2}{*}{ Behavioural factors } & Equal variances assumed. & 8.928 & 0.003 & 1.339 & 998.000 & 0.181 \\
\hline & Equal variances not assumed. & - & - & 1.343 & 996.374 & 0.180 \\
\hline \multirow[t]{2}{*}{ Demand factors } & Equal variances assumed. & 0.981 & 0.001 & 1.832 & 998.000 & 0.067 \\
\hline & Equal variances not assumed. & - & - & 1.833 & 996.244 & 0.067 \\
\hline \multirow[t]{2}{*}{ Supply factors } & Equal variances assumed. & 2.102 & 0.147 & 2.378 & 998.000 & 0.018 \\
\hline & Equal variances not assumed. & - & - & 2.376 & 989.028 & 0.018 \\
\hline
\end{tabular}

The smallest mean value of 1.80 is assigned to the variable Q33, indicating that the selected informal traders did not believe that when they keep their money in the banks, it is easy to access it when they want it. The standard error of the mean values in this analysis is relatively low, indicating that the current sample of the selected informal traders does not vary much from or may only slightly vary from another sample. From the highest standard deviation of 1.164 for variable Q33 and the lowest of 0.880 for variable Q31 it is concluded that the sample of the selected informal traders is homogenous and as such the mean of the selected informal traders is consequently representative of the responses.

The skewness measures obtained for the individual factor variables indicate that two of the variables (Q31 and Q32) have negatively skewed distributions (values $<0$ ), while the other two variables (Q33 and Q34) have positively skewed distribution (values $>0$ ). However, no variable falls outside the -1 range. This indicates normal skewed distributions. The kurtosis values obtained for all the variables in Table 6 indicate relatively flat distributions (negative values) (Pelser 2014).

\section{$t$-Tests: Difference in perception in relation to demographic characteristics of gender and age of the selected informal traders}

The t-tests, analysis of variance and post-hoc analysis were used to ascertain any differences in perception being attributable to demographics characteristics of gender and age of the selected informal traders.

Based on the statistical evidence from Table 7, the independent samples' t-test shows statistically significant results of $p=0.017$ and $p=0.018$ which are both below 0.05 on individual factors and supply factors respectively, indicating that gender differences existed with regard to the two respective variables. These statistical results are in line with Gombrich (2014) who indicates that gender is a factor that affects perception.

On external environmental factors, societal factors, behavioural factors and demand side factors, no significant differences were noted evidenced by $p>0.05$ values of 0.856 , $0.705,0.181$ and 0.067 respectively, implying that gender had no influence on the perception of the respondents on those variables.

\section{Analysis of variance: Difference in perception in relation to demographic characteristics of age}

Table 8 indicates a statistical significance value of 0.000 in all variables indicating significant differences of perception in all the variables within the different age groups and a further post-hoc test was used to ascertain where specifically the differences in perception occurred within the age range group of the selected informal traders.

\section{Post hoc: Test on age}

Table 9 shows an analysis of the different age ranges of the selected informal traders, with the selected informal traders showing differences in perception of all the variables: external environmental factors, societal factors, individual factors, behavioural factors, demand side factors and supply side factors, evidenced by significant values ranging from 0.000 to 0.034 . This implies that the age ranges of $18-30$ years, $31-40$ years and 41-50 years had differing views on the financial inclusion trajectory of the financial sector in Zimbabwe. 
TABLE 8: Analysis of variance.

\begin{tabular}{|c|c|c|c|c|c|c|}
\hline $\begin{array}{l}\text { Financial inclusion } \\
\text { construct pillar }\end{array}$ & Variable & Sum of squares & $d f$ & Mean square & $F$ & Significance \\
\hline \multirow{3}{*}{$\begin{array}{l}\text { External environmental } \\
\text { factors }\end{array}$} & Between groups & 583.725 & 3 & 194.575 & 86.388 & 0.000 \\
\hline & Within groups & 2243.331 & 996 & 2.252 & - & - \\
\hline & Total & 2827.056 & 999 & - & - & - \\
\hline \multirow[t]{3}{*}{ Societal factors } & Between groups & 1068.065 & 3 & 356.022 & 133.106 & 0.000 \\
\hline & Within groups & 2664.014 & 996 & 2.675 & - & - \\
\hline & Total & 3732.079 & 999 & - & - & - \\
\hline \multirow[t]{3}{*}{ Individual factors } & Between groups & 796.733 & 3 & 265.578 & 28.938 & 0.000 \\
\hline & Within groups & 9140.623 & 996 & 9.177 & - & - \\
\hline & Total & 9937.356 & 999 & - & - & - \\
\hline \multirow[t]{3}{*}{ Behavioural factors } & Between groups & 2057.326 & 3 & 685.775 & 75.944 & 0.000 \\
\hline & Within groups & 8993.938 & 996 & 9.030 & - & - \\
\hline & Total & 11051.264 & 999 & - & - & - \\
\hline Demand factors & Between groups & 639.354 & 3 & 213.118 & 21.135 & 0.000 \\
\hline \multirow[t]{3}{*}{ Supply factors } & Between groups & 709.775 & 3 & 236.592 & 47.422 & 0.000 \\
\hline & Within groups & 4969.096 & 996 & 4.989 & - & - \\
\hline & Total & 5678.871 & 999 & - & - & - \\
\hline
\end{tabular}

TABLE 9: Multiple comparisons.

\begin{tabular}{|c|c|c|c|c|c|}
\hline Dependent variable & (I) Age (years) & (J) Age (years) & Mean difference (I-J) & Standard error & Significance \\
\hline \multirow{6}{*}{$\begin{array}{l}\text { External environmental } \\
\text { factors }\end{array}$} & \multirow[t]{2}{*}{$18-30$} & $31-40$ & $1.45775^{*}$ & 0.12101 & 0.000 \\
\hline & & $41-50$ & $-1.89481 *$ & 0.19367 & 0.000 \\
\hline & \multirow[t]{2}{*}{$31-40$} & $18-30$ & $0.52083^{*}$ & 0.12529 & 0.000 \\
\hline & & $41-50$ & 0.29000 & 0.21304 & 0.000 \\
\hline & \multirow[t]{2}{*}{$41-50$} & $18-30$ & $-1.74775 *$ & 0.19367 & 0.000 \\
\hline & & $50+$ & 0.29000 & 0.21304 & 0.524 \\
\hline \multirow{5}{*}{ Societal factors } & $18-30$ & $41-50$ & $3.33500 *$ & 0.22958 & 0.000 \\
\hline & \multirow[t]{2}{*}{$31-40$} & $18-30$ & $-0.66500 *$ & 0.23216 & 0.022 \\
\hline & & $41-50$ & $0.76410 *$ & 0.13187 & 0.000 \\
\hline & \multirow[t]{2}{*}{$41-50$} & $18-30$ & $4.00000 *$ & 0.28260 & 0.000 \\
\hline & & $50+$ & $0.66500 *$ & 0.23216 & 0.022 \\
\hline \multirow[t]{5}{*}{ Individual factors } & \multirow[t]{2}{*}{$18-30$} & $31-40$ & $-2.09511^{*}$ & 0.24427 & 0.000 \\
\hline & & $41-50$ & $-1.99000 *$ & 0.42526 & 0.000 \\
\hline & $31-40$ & $41-50$ & $2.09511^{*}$ & 0.24427 & 0.000 \\
\hline & \multirow[t]{2}{*}{$41-50$} & $18-30$ & $2.99000 *$ & 0.43004 & 0.000 \\
\hline & & $50+$ & 0.89489 & 0.39094 & 0.101 \\
\hline \multirow[t]{6}{*}{ Behavioural factors } & \multirow[t]{2}{*}{$18-30$} & $31-40$ & $-2.51853^{*}$ & 0.24230 & 0.000 \\
\hline & & $41-50$ & $-4.99000 *$ & 0.42184 & 0.000 \\
\hline & \multirow[t]{2}{*}{$31-40$} & $18-30$ & $-4.99000^{*}$ & 0.42658 & 0.000 \\
\hline & & $41-50$ & $2.51853^{*}$ & 0.24230 & 0.000 \\
\hline & \multirow[t]{2}{*}{$41-50$} & $18-30$ & $-2.47147^{*}$ & 0.38256 & 0.000 \\
\hline & & $50+$ & $-2.47147^{*}$ & 0.38779 & 0.000 \\
\hline \multirow[t]{5}{*}{ Demand factors } & \multirow[t]{2}{*}{$18-30$} & $31-40$ & $0.69569 *$ & 0.25604 & 0.034 \\
\hline & & $41-50$ & $2.00500 *$ & 0.44577 & 0.000 \\
\hline & \multirow[t]{2}{*}{$31-40$} & $18-30$ & $-1.99500 *$ & 0.45078 & 0.000 \\
\hline & & $41-50$ & $-0.69569 *$ & 0.25604 & 0.034 \\
\hline & $41-50$ & $18-30$ & $1.30931 *$ & 0.40426 & 0.007 \\
\hline \multirow{5}{*}{ Supply factors } & $18-30$ & $41-50$ & -0.33500 & 0.31355 & 0.709 \\
\hline & \multirow[t]{2}{*}{$31-40$} & $18-30$ & $-2.33500^{*}$ & 0.31708 & 0.000 \\
\hline & & $41-50$ & $1.92959 *$ & 0.18010 & 0.000 \\
\hline & \multirow[t]{2}{*}{$41-50$} & $18-30$ & $-1.59459 *$ & 0.28436 & 0.000 \\
\hline & & $50+$ & $-2.00000 *$ & 0.38595 & 0.000 \\
\hline
\end{tabular}

*, The mean difference is significant at the 0.05 level. 
However, no significant differences were noted on external environmental factors by the age range of 50 and above years with a value of $0.524, p>0.05$, implying a similar perception on individual factors. There was also no significant difference in perception on supply side factors portrayed by the age group $41-50$ years with a value of $0.709, p>0.05$. In summary, perception on financial inclusion was related to the demographic characteristic of the age of the respondents.

\section{Factor analysis: Perceived dominant dimensions of financial inclusion challenges as extracted by factor analysis}

The Kaiser-Meyer-Olkin (KMO) value which measures how suitable the data collected was for this study is 0.952 as shown in Table 10. Statistically a KMO value of 0.952 is a good value to proceed with the test as it is a value above

TABLE 10: Kaiser-Meyer-Olkin and Bartlett's Test.

\begin{tabular}{llc}
\hline Test & Variable & Value \\
\hline $\begin{array}{l}\text { Kaiser-Meyer-Olkin measure of } \\
\text { sampling adequacy }\end{array}$ & - & 0.952 \\
Bartlett's test of sphericity & Approximate chi square & 2051.692 \\
& Df & 300 \\
& Significance & 0.000 \\
\hline
\end{tabular}

0.9 which means the results provide valid conclusions. Furthermore, the associated $p$-value for the Bartlett's test of sphericity is 0.000 which is less than 0.001 .

The total variance in Table 11 shows the eigenvalues and percentage of variance for the four factors of the initial solution which are regarded as important. That table shows that the first factor of the initial solution has a percentage variance of $56.559 \%$ and thus is clearly much important than the other three factors with $4.959 \%, 4.364 \%$ and $4.268 \%$ respectively.

The importance of each of the principal components are shown in Table 11 and only the first four have eigenvalues over 1.00 , and together these four explain over $70 \%$ of the total variability in the data. Thus, this leads to the conclusion that a four-factor solution may probably be adequate to explain the data for this study.

According to Table 12 there are four rotated factors which are plausibly just as good as the initial factors in explaining and reproducing the observed correlation matrix. Moreover, Table 11 details how the variables were distributed into four rotated factors.

TABLE 11: Total variance explained.

\begin{tabular}{|c|c|c|c|c|c|c|}
\hline \multirow[t]{2}{*}{ Component } & \multicolumn{3}{|c|}{ Initial eigenvalues } & \multicolumn{3}{|c|}{ Extraction sums of squared loadings } \\
\hline & Total & $\%$ of variance & Cumulative \% & Total & $\%$ of variance & Cumulative $\%$ \\
\hline 1 & 14.140 & 56.559 & 56.559 & 14.140 & 56.559 & 56.559 \\
\hline 2 & 1.240 & 4.959 & 61.518 & 1.240 & 4.959 & 61.518 \\
\hline 3 & 1.091 & 4.364 & 65.882 & 1.091 & 4.364 & 65.882 \\
\hline 4 & 1.067 & 4.268 & 70.150 & 1.067 & 4.268 & 70.150 \\
\hline
\end{tabular}

\begin{tabular}{|c|c|c|c|c|}
\hline \multirow[t]{2}{*}{ Variable } & \multicolumn{4}{|c|}{ Component } \\
\hline & 1 & 2 & 3 & 4 \\
\hline Q27: I often use my bank account for business transactions & 0.865 & 0.143 & 0.257 & 0.046 \\
\hline Q28: I would use my bank account if I had more regular income & 0.828 & 0.114 & 0.219 & -0.076 \\
\hline Q29: It is easy to incorporate formal banking instruments such as point of sale machines in my business & 0.823 & 0.248 & 0.228 & 0.109 \\
\hline Q33: When I keep my money with the banks it is easy to access it when I want it & 0.806 & 0.127 & 0.060 & 0.130 \\
\hline Q30: I would like to access a loan through a registered micro finance provider & 0.784 & 0.289 & 0.159 & 0.288 \\
\hline Q21: Interest rates that are charged by local banks are low & 0.729 & 0.370 & 0.405 & 0.078 \\
\hline Q26: I have been taught the benefits of using formal financial services & 0.729 & 0.247 & 0.308 & 0.221 \\
\hline Q34: Financial services providers make it easy to take up their products & 0.716 & 0.231 & 0.289 & 0.348 \\
\hline Q20: Bank charges for doing transactions are low making formal banking desirable & 0.705 & 0.328 & 0.351 & 0.201 \\
\hline Q32: Financial services providers offer products that are relevant to my business & 0.682 & 0.282 & 0.260 & 0.269 \\
\hline Q10: Government has policies that support my business financially & 0.679 & 0.072 & 0.331 & 0.129 \\
\hline Q17: I believe that the formal financial services sector has done enough to instill trust in them & 0.652 & 0.352 & 0.130 & 0.283 \\
\hline Q12: The formal financial service providers have enough money to lend to the informal sector & 0.636 & 0.319 & 0.188 & 0.371 \\
\hline Q15: The Zimbabwean financial services sector can be trusted since the Zim dollar era & 0.549 & 0.258 & 0.192 & 0.242 \\
\hline Q22: Filling in bank forms is easy & 0.507 & 0.461 & 0.442 & 0.057 \\
\hline Q16: I believe that registered financial services providers add value to informal traders & 0.487 & 0.385 & 0.373 & 0.326 \\
\hline Q19: It is easy to access a bank or financial services provider & 0.250 & 0.717 & 0.129 & -0.004 \\
\hline Q23: I am aware of the products offered by registered financial services providers & 0.471 & 0.603 & 0.324 & 0.073 \\
\hline Q13: The informal sector comprises people capable of utilising formal financial services & 0.166 & 0.059 & 0.793 & 0.148 \\
\hline Q31: There are many registered financial services providers that are available to me in my area & 0.260 & 0.148 & 0.697 & 0.031 \\
\hline Q24: Savings, investments, unit trusts or shares offered by registered financial service providers are important & 0.294 & 0.429 & 0.529 & 0.286 \\
\hline Q11: It is my opinion that people utilise formal financial products because they are willing to pay tax & 0.126 & 0.461 & 0.032 & 0.726 \\
\hline Q14: Formal financial products are for the rich and big corporates & -0.269 & 0.296 & -0.260 & -0.709 \\
\hline
\end{tabular}


The first factor has a relatively large number of variables including: 'I often use my bank account for business transactions', 'I would use my bank account even if I had more regular income', 'It is easy to incorporate formal banking instruments such as point of sale machines in my business', 'I would like to access a loan through a registered bank or registered micro finance provider', 'The money I earn warrants the opening of a bank account', 'bank charges for doing transactions are low making formal banking desirable', 'interest rates that are charged by local banks are low' and 'Filling in bank forms is easy', just to mention a few.

Demand side factors: The authors believe that it seems reasonable to identify the first rotated factor as 'demand side factors', as all these variables speak of an individual's need and perception towards utilising formal financial services. These variables also have high loadings on the factor. These are: low and irregular income, inadequate information on financial services and products, as well as financial literacy as demand side factors, which it proffers as the major factors constraining financial inclusion in Zimbabwe.

Supply side factors: The second factor extracted has the variables: 'It is easy to access a bank or financial services provider' and 'I am aware of the products offered by registered financial services providers'. These factors point to proximity of financial service providers and awareness of products that they offer. Hence the authors believe that it seems reasonable to identify the second rotated factor as 'supply side factors'.

Behavioural factors: The third factor has the following variables: 'There are many registered financial services providers that are available to me in my area', 'Savings, investments, unit trust or shares offered by registered financial services providers are important' and 'The informal sector comprises people capable of utilising formal financial services'. The researchers believe that it seems reasonable to identify the third rotated factor as 'behavioural factors'.

Individual factors: The fourth factor has the following variables: 'Formal financial products are for the rich and big corporates' and 'It is my opinion that people who utilise formal financial products do so because they are willing to pay tax'. The researchers believe that it seems rational to identify the fourth rotated factor as 'individual factors'. Income levels and affordability contribute significantly to the current levels of financial exclusion.

In summary, the factor analysis procedure identified or extracted these four factors as the perceived dormant dimensions of financial inclusion challenges. Listed in order of significance, they are demand side factors; supply side factors; behavioural factors and individual factors.

\section{Limitations of the research}

This study mainly focuses on the post-multicurrency regime financial inclusion confidence challenges of selected informal traders in the Avondale area of Harare, the capital city of Zimbabwe. There are other sectors like small-scale mining, and small-scale resettled farming. Their status with regard to financial inclusion could have broadened the scope of this study.

\section{Conclusion and recommendations}

Research in financial inclusion has become increasingly prevalent with the consensus that inclusivity of every citizen in the mainstream financial system of an economy is a vital $\operatorname{cog}$ that seems to be missing in most of the economies of the developing countries and emerging economies, Zimbabwe included. The experiences of the hyperinflation era of 2008 in Zimbabwe are still fresh in the minds of Zimbabweans. The citizens lost their hard-earned savings in this wave of hyperinflation. Confidence in the country's financial and banking sector hit an all-time rock bottom during this hyperinflation period.

The main aim of this study was to assess the perceptions of the post-multicurrency regime financial inclusion confidence challenges of the informal traders in Zimbabwe and to explore the influence of the demographic characteristics of the selected informal traders in their perceptions. Therefore the following research questions were addressed in this study:

- What is the general status of financial inclusion among the selected informal traders in Harare?

- To what extent do the selected informal traders in Harare perceive the following as financial inclusion confidence challenges in Zimbabwe: external environmental factors, societal factors, individual factors, demand side factors, behavioural factors, supply side factors?

- Is there a difference in the perception of the financial inclusion confidence challenges in Zimbabwe in relation to demographic characteristics of the selected informal traders in Harare?

- What are the perceived dominant dimensions of financial inclusion confidence challenges as extracted by factor analysis?

Research questions were addressed through descriptive statistics of central tendency and measures of variability. The descriptive statistics indicated that, despite the selected informal traders' high level of literacy and understanding of the financial system in the country, they remain adamant that they would rather continue dealing and operating informally and not open a bank account, that is, keeping their money not circulating in the formal financial system.

This raises a serious question of healing from the financial experiences of the hyperinflation era of 2008. There is still a challenge of confidence in the country's current financial system. Question four was addressed through t-tests, analysis of variance and post hoc statistical analysis, with statistical evidence that the demographic characteristics of age significantly influenced the perceptions of the selected 
informal traders, with the age group above 50 years seemingly indifferent. Finally, question five was addressed through factor analysis of the financial inclusion challenges, and the analysis procedure identified or extracted the four factors as the perceived dominant dimensions of financial inclusion challenges. Listed in order of significance, they are demand side factors, supply side factors, behavioural factors and individual factors.

The current study contributes to knowledge in the fields of economic development and banking by propounding the latent dimensions extracted by factor analysis of potential construct pillars for achieving optimal financial inclusion in the informal sector of a multicurrency regime economy recovering from hyperinflation. This creates a good basis for further future grounded theory studies that could generate a theory or framework for achieving optimal financial inclusion in a country such as Zimbabwe. The proposed construct pillars to mitigate the negative perceptions towards financial inclusion by the informal sector are the following: demand side factors, supply side factors, behavioural factors and individual factors, in that order.

The envisaged future developed framework or theory would also minimise the negative impacts of the general mistrust of formal financial service providers, which seemed to be prevalent among the age group 18 years to 40 years of the informal traders, and would aid the government to craft policies that would be perceived to be supportive of the informal sector. The authors recommend a future case study, grounded in theory, to confirm in a concrete theory the current study's claim on the framework developed. It is critical that the central bank, policymakers in government, bankers, financial institutions and captains of industries come together and formulate banking policies that are user friendly and beneficial to the informal sector in the country. There is a significant proportion of the population that is not formally employed but gainfully engaged economically, whose number is estimated at well above $90 \%$ of the potentially employable population.

The study recommends policy consistency and good corporate governance to be observed by policymakers to instill trust and confidence in the informal sector and the general populace in the financial services sector in the postmulticurrency adoption period and hyperinflation era. The study also suggests a need for Zimbabwe to restore human rights, political stability, and ensure compliance with the Financial Action Task Force (FATF) regulations regarding money laundering and terror financing in order to boost external confidence in the financial system of the country as well. However, compliance with FATF on money laundering and terror financing requirements may prove to be a significant obstacle to this cause. The cost of borrowing, such as interest rates, should be lowered and the processing of loan applications should be faster, to motivate the informal traders to believe that there is added business value in using formal financial services. Given the high costs of developing viable banking systems particularly in the rural areas, technology advances, such as mobile banking (e.g. Ecocash, Onewallet and Telcash) could be a promising way to facilitate optimal financial inclusion in Zimbabwe.

\section{Acknowledgements Competing interests}

The authors declare that they have no financial or personal relationships that may have inappropriately influenced them in writing this article.

\section{Authors' contributions}

B.N. is the lead and corresponding author and performed the statistical analysis for the article as well. T.P. provided the academic guidance in the writing of the article. T.C. administered the data collection processes and coded the data for analysis.

\section{References}

Adisu, M., 2006, 'Micro-finance repayment problems in the informal sector in Addis Ababa', Ethiopian Journal of Business and Development 1(2), 29-50.

Allen, F., Carletti, E., Culle, R., Qian, J., Senbet, L. \& Valenzuela, P., 2014, 'The African financial development and financial inclusion gaps', Journal of African Economies 23(5), 614-642. https://doi.org/10.1093/jae/eju015

Anderloni, L. \& Carluccio, E., 2006, 'Access to bank accounts and payment services', in L. Anderloni, E. Carluccio \& M. Braga (eds.), New frontiers in banking services: Emerging needs and tailored products for untapped markets, pp. 5-105, Springer, Verlag, Berlin.

Arun, T. \& Kamath R., 2015, 'Financial inclusion: Policies and practices', IIBM Management Review 27(4), 267-287. https://doi.org/10.1016/j.iimb.2015.09.004

Atkinson, A. \& Messy, F., 2013, Promoting financial inclusion through financial education.pdf, viewed 16 February 2017, from http://ezproxyucdc.ucatolica.edu. co:2053/docview/1445700474/D1C97442B3814E13PQ/264?Accountid $=45660$

Beck, T. \& De La Torre, A., 2006, The basic analytics of access to financial services, Policy Research Work Paper 4026, World Bank, Washington, DC.

BMRB, 2006, Access to financial services by those on the margins of banking: Final report for the financial inclusion taskforce, BMRB, London.

Braga, M.D., 2006, 'Access to investments and asset building for low income people', in L. Anderloni, M. Braga \& E.M. Carluccio (eds.), New frontiers in banking services: Emerging needs and tailored products for untapped markets, pp. 141-190, Springer, Verlag, Berlin.

Chakraborry, K., 2003, 'Financial education', address at the India-OECD-World Bank Regional Conference, New Delhi, 04 March.

Chakraborry, K., 2012, 'Financial inclusion', address at the India-OECD-World Bank Regional Conference, New Delhi, 06 April.

Chakravarty, S.R. \& Pal, R., 2013, 'Financial inclusion in India: An axiomatic approach', Journal of Policy Modeling 35(5), 813-837. https://doi.org/10.1016/j.jpolmod. 2012.12.007

Chitokwindo, S., Mago, S. \& Hofisi, C., 2014, 'Financial inclusion in Zimbabwe: A contextual overview', Mediterranean Journal of Social Sciences 5(20), 415-423. https://doi.org/10.5901/mjss.2014.v5n20p415

Claessens, S., 2006. 'The links between finance and inequality: Channels and evidence', background paper for World Development Report 2006, World Bank, Washington, DC.

Corr, C., 2006, Financial exclusion in Ireland: An exploratory study \& policy review, Research Series 39, Combat Poverty Agency, Dublin.

Cull, R., Demirgüç-Kunt, A. \& Lyman, T., 2012, Financial inclusion and stability, CGAP brief, May 2008, CGAP, Washington, DC

De Koker, L. \& Jentzsch, N., 2013, 'Financial inclusion and financial integrity: Aligned incentives?', World Development 44, 267-280. https://doi.org/10.1016/j. worlddev.2012.11.002

Demirgüç-Kunt, A. \& Klapper, L., 2012a, Measuring financial inclusion: The globa findex database, World Bank Policy Research Working Paper 6025 (April) pp. 1-61, viewed 25 February 2017, from http://elibrary.worldbank.org/doi/ book/10.1596/978-0-8213-9509-7

Demirgüç-Kunt, A. \& Klapper, L., 2012b, Financial inclusion in Africa: An overview, Policy Research Working Paper No. 6088, World Bank, Washington, DC.

Financial Inclusion Centre UK, 2016, The causes of financial exclusion, viewed 2017 from http://inclusioncentre.co.uk/wordpress29/the-financial-inclusion-challenge/ the-causes-of-financial-exclusion 
FINCA International, 2016, Financial inclusion, viewed 27 February 2017, from http:// www.finca.org/our-impact/improved-lives/financial-inclusion/Finscope Consumer Survey Zimbabwe.

Ghatak, A., 2013, 'Demand side factors affecting financial inclusion', Research Journal of Social Science \& Management, 3(1), 2251-2157.

Global Microscope, 2015, The enabling environment for financial inclusion, Washington, DC

Gombrich, R., 2014. 'Critical reflection of women's empowerment and gender equality from 1994', commissioned paper, Department of Performance Monitoring and Evaluation, Pretoria.

Gupte, R., Venkataramani, B. \& Gupta, D., 2012, 'Computation of financial inclusion index for India', Procedia -Social and Behavioral 37(5), 33-149. https://doi. org/10.1016/j.sbspro.2012.03.281

HM Treasury, 2004, 'Promoting financial inclusion', Poverty Eradication 114(7), 10-14, viewed 23 February 2017, from http://www.tandfonline.com/doi/abs/10.1080/0 $0014788.2000 .9728939 \% 5 \mathrm{Cnhttp}$ ://search.ebscohost.com/login.aspx?direct=tru 0014788.2000.9728939\%5Cnhttp://search
e\&db=bth\&AN=11897588\&site=ehost-live

Hussmanns, R., 2004, Measuring the informal economy: From employment in the informal sector to informal employment, Working Paper No. 53, Policy Integration informal sector to informal employment, Working Paper No. 53, Policy In
Department Bureau of Statistics International Labour Office, Geneva.

International Labour Organisation, 2015, Transition from the informal economy recommendation 204, viewed 28 February 2017, from http://www.ilo.org/ilc/ ILCSessions/104/texts-adopted/WCMS 377774/lang--en/index.htm

International Monetary Fund (IMF)-Zimbabwe, 2010, Challenges and policy options after hyperinflation, Washington, DC

Kairiza, T., Kiprono, P. \& Magadzire, V., 2016, 'Gender differences in financial inclusion amongst entrepreneurs in Zimbabwe', Small Business Economics 71(3), 1-14.

Kempson, E., 2006, 'Policy level response to financial exclusion in developing economies: Lessons for developing countries', paper for Access to finance: Building inclusive financial systems, 30-31 May 2006, World Bank, Washington, DC.

Kodan, A.S., 2011, 'Financial inclusion: IUP', Journal of Financial Economics 6(2), 27-40.

Lee, E. \& Vivarelli, M., 2004, Understanding globalization, employment and poverty reduction, Palgrave Macmillan, New York.

Lindsey, P.A., Romañach, S.S., Tambling C.J., Chartier, K. \& Groom, R., 2011, 'Ecologica and financial impacts of illegal bush meat trade in Zimbabwe', Oryx 45(1), 96-111. https://doi.org/10.1017/S0030605310000153

Mago, S., 2014, 'The impact of mobile banking on financial inclusion in Zimbabwe: A case for Masvingo Province', Mediterranean Journal of Social Sciences 5(9), 221-230.

Makoni, W., 2010, 'Insiders and outsiders: The choice between informed and arm'slength debt', Journal of Finance, 47(4), 1367-1400.

Memdani, L. \& Rajyalakshmi, K., 2013, 'Financial inclusion in India', International Journal of Applied Research and Studies 2(8), 2278-9480.
Morgan, P.J. \& Pontines, V., 2014, Financial stability and financial inclusion, viewed 34 March 2017, from http://www.adbi.org/working-paper/2014/07/07/6353. financial.stability.inclusion/

Munyanyi, W., 2013, 'Banking the unbanked: Is financial inclusion powered by Ecocash a veracity in rural Zimbabwe?', Month Greener Journal of Banking and Finance $1(1), 1-9$.

Munyanyi, W., 2014, 'Women financial inclusion in Zimbabwe: A descriptive comparison of rural and urban populaces', International Journal of Education and Research 2(6), 234-345.

Ncube, M., 2013, Recognizing Africa's informal sector, African Development Bank, Washington, DC.

Ndlovu, I. \& Ndlovu, M., 2013, 'Mobile banking the future to rural financial inclusion: Case study of Zimbabwe', IOSR Journal of Humanities and Social Sciences 9(4), 70-75. https://doi.org/10.9790/0837-0947075

Njaya, T., 2015, 'Informal sector, Panacea to the high unemployment in Zimbabwe? Case of informal sector enterprises of Harare Metropolitan', International Journal of Research in Humanities and Social Studies 2(2), 97-106.

Noko, J., 2011, 'Dollarization: The case of Zimbabwe', Cato Journal 31(2), 339-365.

Nuewirth, R., 2012, 'Stealth of nations the global rise of the informal economy', Cato Journal 29(1), 139-166.

Owusu-Ansah, S., 2000, 'Timeliness of corporate financial reporting in emerging capital markets: Empirical evidence from the Zimbabwe Stock Exchange Accounting and Business Research 30(3), 241-254. https://doi.org/10.1080/0001 4788.2000.9728939

Pelser, G.T., 2014, 'Sustaining industry leadership through innovation strategy archetypes', International Business \& Economics Research Journal 13(4), 1234-1248. https://doi.org/10.19030/iber.v13i4.8679

Prices Incomes, Consumption and Expenditure Survey (PICES), 2012, RBZ, Harare.

Reserve Bank of Zimbabwe (RBZ), National Financial Inclusion Strategy, 2016, Government of Zimbabwe, Harare.

Sarma, M., 2008, Index of financial inclusion, Working Paper No. 215, Indian Council for Research on International Economic Relations, New Delhi.

Sarma, M., 2011, 'Financial inclusion', Journal of International Development 62(8), 613-628. http://doi.wiley.com/10.1002/jid.1698

Sarma, M., 2012, 'Index of financial inclusion - A measure of financial sector inclusiveness,' Journal of International Development 73(9), 714-734.

Shankar, F., 2007, Removing barriers to formalization, in promoting pro-poor growth Policy guidance for donors, OECD Publishing, Paris.

Shankar, F., 2013, 'How economic contractions and expansions affect expenditure patterns,' Journal of Consumer Research, 39(2), 229-247.

Zimbabwe Economic Policy Analysis and Research Unit (ZEPARU), 2016, 'Economic Policy Analysis and Management', World Bank, Geneva.

Zimbabwe National Statistic Agency, 2016, Quarterly digest of statistics, Government of Zimbabwe, Harare. 